Что касается подкупа высших должностных лиц, то тут требуется большая ответственность, внимание и проработка самого действия, чтобы не возникли неприятности, в виде уголовной ответственности за дачу взятки.

Ниже на примере 2017, 2018 и 2019 годов рассмотрим статистику противодействия коррупции в таможенных органах.

За 2017 год по противодействию коррупции было возбуждено 406 уголовных дел.

За 2018 год по противодействию коррупции возбуждено 251 уголовное дело.

За 1-е полугодие 2019 год по противодействию коррупции возбуждено 248 уголовных дел 3 .

По представленной статистики видно, что ведется активная работа по выявлению коррупционных преступлений в таможенных органах. Также можем судить о том, что данная работа правоохранительных органов весьма продуктивна.

С момента утверждения международных договоров, таких как: (Международный кодекс поведения государственных должностных лиц (принят Генеральной Ассамблеей $\mathrm{OOH}$ 12.12.1996); Конвенцию ООН против коррупции (принята Генеральной Ассамблеей $\mathrm{OOH}$ 31.10.2003), развитие проблемы коррупции приобрело более значимый вид, поскольку, с этого момента российское законодательство получило развитие в данной сфере.

В России в 2008 году принимается Ф3 «О противодействии коррупции», который помогает в борьбе с ней.

Для борьбы с коррупцией, в том числе в таможенных органах, создан Указ Президента РФ от 29.06.18 № 378 «О Национальном плане противодействия коррупции на 2018-2020годы ${ }^{4} »$.

Применение данных актов дает возможность увеличить результативность борьбы с коррупционными преступлениями.

Акцент делается на таких методах противодействию коррупции, как:

- активная работа по минимизации коррупционных отношений способами кадрового и административного характера;

- повышение производительности деятельности государственной службы;

- улучшение системы профессиональной подготовки и переподготовки сотрудников;

- внедрение систематизированного кадрового отбора претендентов в сотрудники таможенных органов;

- оснащение улучшенным техническим оборудованием подразделение таможенных органов.

Следующий пример приведен в качестве наглядного доказательства деятельности таможенных антикоррупционных подразделений.

Самарским следственным отделом на транспорте Приволжского следственного управления на транспорте СК России по материалам службы по противодействию коррупции Самарской таможни в октябре 2018 года было возбуждено уголовное дело в отношении главного государственного инспектора за получение взятки в размере 132000 рублей, в следствии оказания содействия при таможенном оформлении 5 .

Исходя из всего вышесказанного, следует заметить, что на данный момент в России действует весьма эффрективная система по противодействию коррупции. Несомненно, ущерб от этого явления наносит как государству, так и гражданам страны. Данные приемы и анализы, позволят дальнейшему развитию сферы противодействия коррупции. 
1 Федеральный закон "О противодействии коррупции" от 25.12.2008 N 273-Ф3//принят Государственной Думой 19 декабря 2008 года. (дата обращения: 02.10.19)

2 Маликова А.Ш. Причины и условия, способствующие возникновению коррупции [Электр. ресурc]. - 2015.

3 Результаты работы Управления по противодействию коррупции http://customs.ru/activity/ protivodejstvie-korrupczii/doklady,-otchety,-obzory,-statisticheskaya-informacziya/rezul-taty-rabotyupravleniya-po-protivodejstviyu-korrupczii. (дата обращения: 02.10.19)

4 Указ Президента РФ от 29.06.18 № 378 «О Национальном плане противодействия коррупции на 2018-2020 годы» // СПС «Консультант». (дата обращения 02.10.19)

${ }^{5}$ Сайт фредеральная таможенная служба. http://customs.ru. (дата обращения 02.10.19)

\title{
ANTI-CORRUPTION IN THE SPHERE OF CUSTOMS AUTHORITIES OF THE RUSSIAN FEDERATION
}

\author{
C 2019 Rusanova Diana Yuryevna \\ Student \\ C2019 Paulov Pavel Alexandrovich \\ Ph. D., Associate Professor of Public Law \\ Samara State University of Economics \\ E-mail: Rusanovadiana1998@gmail.com.paulovpavel@yandex.ru
}

Keywords: customs authorities, corruption, causes of corruption, anti-corruption, control in the field of customs authority, corruption crimes.

This article is devoted to combating corruption in the field of customs authorities of the Russian Federation. The relevance of the topic is that it is necessary to increase the anti-corruption system of customs authorities. An attempt to identify the causes of corruption. The article presents the statics of initiation of criminal cases in relation to the corruption component.

УДК 343.98

Код РИНЦ 10.85 .00

\section{ПРИМЕНЕНИЕ ЦИФРОВОЙ ФОТОГРАФИИ В РАССЛЕДОВАНИИ ПРЕСТУПЛЕНИЙ}

\author{
(c) 2019 Салахов Денис Фанисович \\ магистрант \\ (c) 2019 Милова Ирина Евгеньевна \\ кандидат юридических наук, доцент \\ Самарский государственный экономический университет \\ E-mail: irina.milova@ro.ru
}

Ключевые слова: криминалистическая фотография, цифровая фотокамера, следственные действия, криминалистическая экспертиза. 